description of Marie Antoinette's flight to Varennes, and has the advantage of a happy ending. In 1873 Dagron patented a microfilm viewer designed for use by the French Army for microphotographic maps, and he was active in the field till after 1889 when he exhibited in the Paris World's Fair.

Appended to accounts of the work of Dancer, Dagron, and other nineteenth century microphotographers, are translations of Dagron's two principal publications and an account of the balloon service during the siege of Paris. There are biographical notes on many persons connected with the art and a chronology of microfilm developments. This book is being published in an edition of 500 printed copies and will be kept permanently in print in microfilm and micropaper. The complete bibliography of sources consulted is not included in the printed version, but will be given in the microformat editions.-Hubbard W. Ballou, Photographic Services, Columbia University Libraries.

\section{Library Resources in the}

\section{Southeast}

The Humanities, the Sciences, and the Library in the Southeast: Proceedings of the First Southern College and Research Library Workshop, June 26, 1958. Tallahassee: Florida State University Library School, 1958. 67p. \$1.00. Paper.

The first Southern College and Research Library Workshop, sponsored by the Library School of the Florida State University in the summer of 1958, provided scholars and librarians with the opportunity to consider and to discuss the library resources available for research in the South, or more specifically the Southeast. With the publication of The Humanities, the Sciences, and the Library in the Southeast, the papers presented at this workshop are now available in an attractive format.

Eight of the papers presented at the workshop are included in the proceedings here under review. In the keynote address, "Research, Resources, and Librarianship in the
Southeast," Benjamin E. Powell, Duke University librarian, presents with skill and understanding the background against which the strengths and weaknesses of the region's libraries may be viewed. The four papers which follow Dr. Powell's describe and comment upon in some detail trends and directions in research in the humanities and the sciences. Dr. Sarah Herndon of the Florida State University English faculty and Dean Werner A. Baum of the FSU Graduate School, representing respectively the humanities and the sciences, present the scholar's view of Southeastern libraries, their resources and their problems. W. Stanley Hoole, University of Alabama librarian, and Dorothy M. Crosland, Georgia Institute of Technology director of libraries, describe some of the difficulties librarians face in attempting to meet the needs of scholars once they have been determined. Willard O. Mishoff, formerly specialist for college and research libraries in the United States Office of Education and now librarian of the Mississippi State College for Women; Robert B. Downs, dean of library administration, University of Illinois; and Graham Roberts, library consultant, Southern Regional Education Board, consider in their papers the resources of Southeastern libraries and the program of and plans for interlibrary cooperation in the region.

Librarians from nine Southeastern states (Alabama, Florida, Georgia, Kentucky, Mississippi, North Carolina, South Carolina, Tennessee, Virginia) reported on the research collections available in the libraries of their respective states. Their reports are published as an appendix to the workshop proceedings, and they should prove useful to scholar and librarian alike.

While much remains to be done to strengthen Southeastern libraries, even a cursory reading of these papers and reports will reveal that great progress has been made and that there are distinguished library collections in the South.

The committee which planned the workshop is to be commended highly for its selection of speakers and discussants. The papers here published are both informative and well written._John David Marshall, University of Georgia Library. 